An Introduction to

Electrical Circuit Theory 
Other Titles in Electrical and Electronic Engineering

G. B. Clayton, Data Converters

G. B. Clayton, Experiments with Operational Amplifiers

G. B. Clayton, Linear Integrated Circuit Applications

J. C. Cluley, Electronic Equipment Reliability

R. F. W. Coates, Modern Communication Systems

A. R. Daniels, Introduction to Electrical Machines

C. W. Davidson, Transmission Lines for Communications

W. Gosling, A First Course in Applied Electronics

B. A. Gregory, An Introduction to Electrical Instrumentation

Paul A. Lynn, An Introduction to the Analysis and Processing of Signals

A. G. Martin and F. W. Stephenson, Linear Microelectronic Systems

R. G. Meadows, Electrical Communications Theory, Worked Examples and Problems

J. E. Parton and S. J. T. Owen, Applied Electromagnetics

A. Potton, An Introduction to Digital Logic

Trevor J. Terrell, Introduction to Digital Filters

J. T. Wallmark and L. G. Carlstedt, Field-Effect Transistors in Integrated Circuits 


\title{
An Introduction to Electrical Circuit Theory
}

\author{
G. Williams
}

Lecturer in Electrical Engineering

School of Applied Sciences

University of Sussex

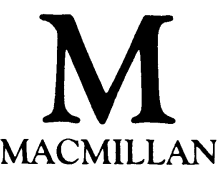


두 G. Williams 1973

All rights reserved. No reproduction, copy or transmission of this publication may be made without written permission

No paragraph of this publication may be reproduced, copied or transmitted save with written permission or in accordance with the provisions of the Copyright, Designs and Patents Act 1988, or under the terms of any licence permitting limited copying issued by the Copyright Licensing Agency, 90 Tottenham Court Road, London WIP 9HE.

Any person who does any unauthorised act in relation to this publication may be liable to criminal prosecution and civil claims for damages.

First published 1973 by

THE MACMILLAN PRESS LTD

Houndmills, Basingstoke, Hampshire RG21 2XS

and London

Companies and representatives

throughout the world

ISBN 978-1-349-01683-9

ISBN 978-1-349-01681-5 (eBook)

DOI 10.1007/978-1-349-01681-5

Reprinted 1975 (with corrections), 1977, 1979, 1981, 1982, 1985, 1992 


\section{Contents}

Preface $\quad$ ix

1 BASIC DEFINITIONS AND CIRCUIT LAWS 1

1.1 Units and dimensions 1

1.1.1 Electrical quantities 1

1.1.2 Dimensional analysis 3

1.2 The circuit element of resistance 4

1.2.1 Ohm's law 5

$\begin{array}{lll}\text { 1.2.2 Non-linear resistors } & 7\end{array}$

1.2.3 Power dissipated by resistors 7

1.3 Kirchhoff's laws $\quad 8$

$\begin{array}{lll}1.3 .1 & \text { Sign conventions } & 8\end{array}$

1.3.2 Ideal circuit elements 9

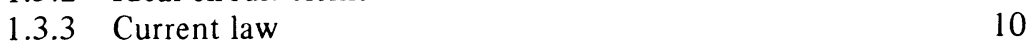

$\begin{array}{lll}1.3 .4 & \text { Voltage law } & 11\end{array}$

1.3.5 Applications of Kirchhoff's laws $\quad 12$

Problems 16

2 METHODS OF ANALYSIS AND NETWORK THEOREMS 18

2.1 Terminology and network topology 18

2.2 The basic method of network analysis 21

2.2.1 Worked example 22

2.3 Mesh analysis 23

2.3.1 Mesh currents 23

2.3.2 Method of mesh analysis 24

2.3.3 Worked example 25

2.3.4 General solution 25

2.4 Nodal analysis 26

2.4.1 Method of nodal analysis 27

$\begin{array}{ll}2.4 .2 \text { Worked example } & 27\end{array}$

2.4.3 General solution 28

2.4.4 Mesh or nodal analysis? 29 
2.5 Duality

2.5.1 Dual networks 29

$\begin{array}{ll}\text { 2.5.2 Sign conventions } & 31\end{array}$

$\begin{array}{ll}2.5 .3 \text { Worked example } & 32\end{array}$

$\begin{array}{lll}2.6 & \text { Sources } & 32\end{array}$

2.6.1 Representation of physical sources 33

$\begin{array}{ll}2.6 .2 \text { Source equivalence } & 35\end{array}$

2.6.3 Compound sources $\quad 35$

2.6.4 Resistanceless sources 36

2.6.5 Maximum power transfer theorem $\quad 39$

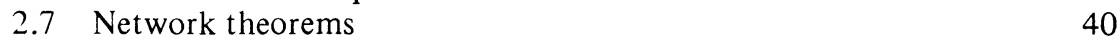

$\begin{array}{lll}2.7 .1 & \text { Linearity } & 40\end{array}$

2.7.2 Superposition theorem 41

2.7.3 Star-delta transformation $\quad 43$

2.7.4 Thévenin's theorem $\quad 47$

$\begin{array}{lll}2.7 .5 & \text { Norton's theorem } & 49\end{array}$

2.7.6 Reciprocity theorem $\quad 51$

2.8 Equivalent $\mathrm{T}$ and $\Pi$ circuits $\quad 52$

2.8.1 Two-port parameters $\quad 53$

2.8.2 Equivalent T circuits $\quad 54$

2.8.3 Equivalent $\Pi$ circuits $\quad 55$

2.8.4 П-T equivalence $\quad 56$

$\begin{array}{lr}\text { Problems } & 56\end{array}$

\section{THE CIRCUIT ELEMENTS OF CAPACITANCE AND INDUCTANCE}

3.1 Capacitance

3.1.1 Definition 61

$\begin{array}{lll}3.1 .2 & \text { Volt-ampere equations } & 62\end{array}$

$\begin{array}{lll}3.1 .3 & \text { Energy stored } & 63\end{array}$

3.1.4 Capacitances in parallel $\quad 64$

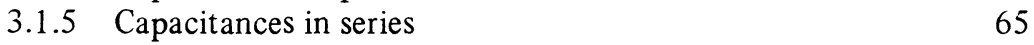

$\begin{array}{ll}3.2 \text { Inductance } & 66\end{array}$

3.2.1 Definition of self-inductance $\quad 66$

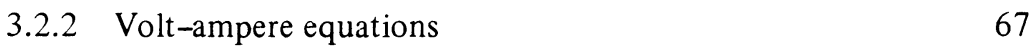

$\begin{array}{lll}3.2 .3 & \text { Energy stored } & 68\end{array}$

$\begin{array}{ll}3.2 .4 & \text { Inductances in series }\end{array}$

$\begin{array}{ll}3.2 .5 & \text { Inductances in parallel }\end{array}$

$\begin{array}{lll}3.3 & \text { Duality } & 70\end{array}$

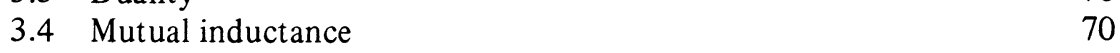

$\begin{array}{lll}3.4 .1 & \text { Definition of mutual inductance } & 70\end{array}$

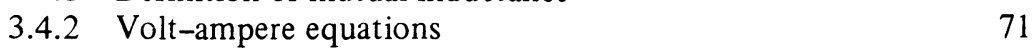

$\begin{array}{lll}3.4 .3 & \text { Equivalent voltage generators } & 72\end{array}$

$\begin{array}{lll}3.4 .4 & \text { Coefficient of coupling } & 73\end{array}$

$\begin{array}{ll}\text { 3.4.5 Magnetic energy stored by mutual inductance } & 73\end{array}$

$\begin{array}{ll}\text { Problems } & 75\end{array}$ 
4 TRANSIENT RESPONSE OF FIRST-AND SECOND-ORDER NETWORKS

$\begin{array}{lll}\text { 4.1 Differential equations of first-order networks } & 78\end{array}$

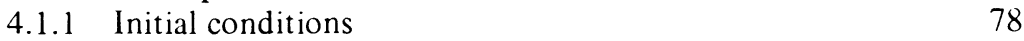

4.1.2 Final conditions $\quad 80$

4.1.3 Application of the basic analytical method 81

4.1.4 Mesh analysis $\quad 82$

4.1.5 Nodal analysis $\quad 82$

4.1.6 Application of network theorems 83

4.2 Natural response of first-order networks 83

4.2.1 RC circuit $\quad 83$

4.2.2 $R L$ circuit $\quad 85$

4.3 Some steady-state responses of first-order networks 86

4.3.1 Series $R L$ circult excited by a step function 86

4.3.2 Series $R C$ circuit excited by a step function 87

4.3.3 Series $R L$ circuit excited by a sinusoidal function $\quad 87$

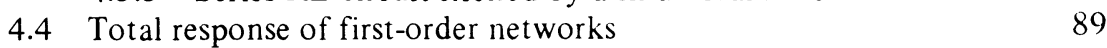

4.4.1 Step response of $R L$ circuits $\quad 89$

4.4.2 Repetitive step response of $R L$ circuit 91

4.4.3 Step response of $R C$ circuit $\quad 92$

4.4.4 Repetitive step response of $R C$ circuit 93

4.5 Differential equations of second-order networks 95

4.6 Natural response of second-order networks 96

4.6.1 Overdamped case 98

4.6.2 Critically damped case $\quad 99$

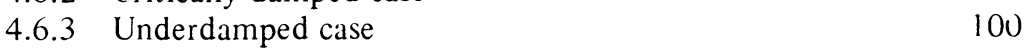

4.6.4 Zero damping case $\quad 101$

$\begin{array}{ll}\text { 4.6.5 Definitions } & 101\end{array}$

$\begin{array}{lll}4.7 & \text { Step response of second-order networks } & 102\end{array}$

$\begin{array}{lll}4.8 & Q \text {-factor } & 104\end{array}$

$\begin{array}{ll}\text { Problems } & 104\end{array}$

5 STEADYSTTATE SINUSOIDAL RESPONSE OF NETWORKS 110

$\begin{array}{lll}5.1 & \text { Response of series } R L C \text { circuit } & 110\end{array}$

$\begin{array}{ll}5.2 \text { Frequency response } & 113\end{array}$

5.2.1 Amplitude 113

5.2.2 Phase 113

$\begin{array}{lll}5.3 Q \text {-factor, bandwidth and resonance } & 114\end{array}$

$\begin{array}{ll}5.4 \text { A.C. quantities } & 118\end{array}$

5.4.1 Instantaneous, mean and r.m.s. values $\quad 119$

$\begin{array}{ll}\text { 5.4.2 Real and reactive power } & 122\end{array}$

$\begin{array}{lll}5.5 & \text { Representation of sinusoids } & 127\end{array}$

$\begin{array}{lll}\text { 5.5.1 Rotating vectors } & 127\end{array}$

5.5.2 Complex number representation of sinusoids 132 
$\begin{array}{lll}5.6 & \text { Frequency-domain analysis } & 136\end{array}$

5.6.1 Volt-ampere equations in the frequency domain 136

5.6.2 Kirchhoff's laws in the frequency domain 140

$\begin{array}{ll}\text { 5.6.3 Mesh and nodal analysis } & 141\end{array}$

5.6.4 Impedance and admittance $\quad 144$

$\begin{array}{lll}5.7 & \text { Worked example } & 145\end{array}$

$\begin{array}{ll}\text { 5.7.1 By phasor diagram } & 145\end{array}$

$\begin{array}{ll}\text { 5.7.2 By nodal analysis } & 147\end{array}$

$\begin{array}{ll}\text { 5.7.3 By Thévenin substitution } & 149\end{array}$

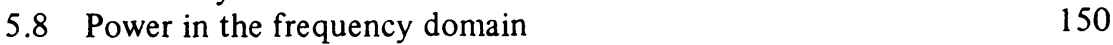

$\begin{array}{ll}\text { 5.8.1 Real, reactive and apparent power } & 150\end{array}$

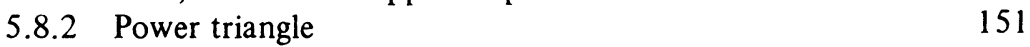

$\begin{array}{ll}\text { 5.8.3 Worked example } & 154\end{array}$

5.8.4 Maximum power transfer theorem 156

$\begin{array}{ll}\text { Problems } & 158\end{array}$

6 NETWORK ANALYSIS TECHNIQUES 164

$\begin{array}{lll}6.1 & \text { Two-port networks } & 164\end{array}$

$\begin{array}{ll}\text { 6.1.1 Open-circuit impedance parameters } & 165\end{array}$

$\begin{array}{ll}\text { 6.1.2 Short-circuit admittance parameters } & 166\end{array}$

$\begin{array}{ll}\text { 6.1.3 Hybrid parameters } & 167\end{array}$

$\begin{array}{ll}\text { 6.1.4 Inverse-hybrid parameters } & 167\end{array}$

$\begin{array}{ll}\text { 6.1.5 Transmission parameters } & 168\end{array}$

$\begin{array}{ll}\text { 6.1.6 Interrelation of parameters } & 169\end{array}$

6.1.7 Equivalent $\mathrm{T}$ and $\Pi$ networks $\quad 171$

$\begin{array}{ll}6.2 \text { Ideal transformer } & 173\end{array}$

$\begin{array}{lll}\text { 6.2.1 Volt-ampere equations } & 173\end{array}$

$\begin{array}{ll}\text { 6.2.2 Impedance transformation } & 175\end{array}$

$\begin{array}{ll}\text { 6.2.3 Voltage and magnetic flux waveforms } & 176\end{array}$

$\begin{array}{ll}\text { 6.2.4 Phasor diagrams } & 177\end{array}$

$\begin{array}{ll}6.2 .5 \text { Worked example } & 179\end{array}$

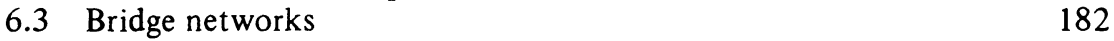

$\begin{array}{ll}\text { 6.3.1 Wheatstone bridge } & 183\end{array}$

$\begin{array}{ll}\text { 6.3.2 Maxwell bridge } & 183\end{array}$

$\begin{array}{lll}6.4 & \text { Polyphase circuits } & 184\end{array}$

$\begin{array}{ll}\text { 6.4.1 Balanced three-phase voltages } & 184\end{array}$

$\begin{array}{ll}\text { 6.4.2 Balanced three-phase currents } & 188\end{array}$

$\begin{array}{ll}\text { 6.4.3 Three-phase power } & 191\end{array}$

6.5 Non-linear circuits-load line and linear approximation 192

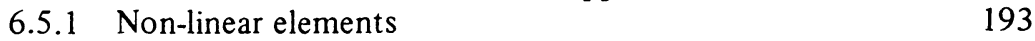

$\begin{array}{ll}\text { 6.5.2 Analytical techniques } & 194\end{array}$

$\begin{array}{ll}\text { Problems } & 198\end{array}$

Solutions to Problems $\quad 200$

$\begin{array}{ll}\text { Index } & 205\end{array}$ 


\section{Preface}

Many textbooks owe their origins to undergraduate lecture courses; this book had its beginnings in a lecture course in engineering science given by the author at the University of Sussex. When the course was begun several years ago the familiar problem of not being able to recommend a single, inexpensive, book to the students taking the course was encountered. The nature of the course structure at Sussex with its major and minor subjects made the problem more difficult because the students attending the course included not only electrical and electronic engineers but undergraduates from many other scientific disciplines too. Educational experiments in the presentation of course material being conducted at the time also meant that printed lecture notes were prepared for the course and it is with these that this book had its beginnings.

While the course contained much circuit theory other topics were included which do not appear here and conversely this book contains several topics not covered in the course. The additional material has been included so that the book may be considered to be an introduction to the subject of circuit theory viewed as a separate discipline and not viewed as a service subject to other disciplines.

The philosophy governing the presentation of the material is that all the circuit laws, methods of analysis and circuit theorems are developed using the simplest possible circuits containing only resistances and d.c. sources. Thus the discussion is not clouded by the examination of the more complicated circuit elements and sources which introduce time variations; the intention is for the student to master the analytical techniques before he goes on to apply them to the more complicated circuits. Application of the techniques to frequency domain circuits is then a logical step which allows the student to concentrate on the frequency domain concepts.

The background knowledge of readers is assumed to be school mathematics and physics but to include no circuit theory. It is also assumed that students will be covering such topics as complex numbers, second-order differential equations and linear algebra simultaneously with their studies of circuit theory and such mathematical topics are not discussed in detail here.

I would like to acknowledge the advice, co-operation and support I have received from my colleagues at the University of Sussex. It is also no cliche to say that this book could not have been created without the active assistance, tolerant 
understanding and unflagging encouragement of my wife.

Many of the problems in this book were originally devised by me for Preliminary Year examinations of the University of Sussex and I am grateful to the University of Sussex for permitting me to use them.

G. W. 